\title{
The Impact of Gender on the Principled Moral Reasoning of Kuwait Education Students
}

\author{
Djilali Bouhmama, Ph.D. \\ Fawzeah Obied Al-Masoud, Ph.D. \\ College of Education \\ Kuwait University \\ Kuwait
}

\begin{abstract}
Using Lawrence Kohlberg's cognitive moral development theory as the guiding theory, the present study was designed to investigate the principled moral reasoning of 67 undergraduate students at the University of Kuwait (27 males and 40 females). Their age ranged from 19 to 24 (Mean age $=18.64$ years, $S D=1.20$ years). A major purpose of the study was to explore the impact of gender on their moral reasoning.Moral reasoning of the participants in the study was measured by the Defining Issues Test (DIT), a widely employed tool for measuring moral reasoning .The data collected were analyzed using the descriptive statistics of, means, and standard deviations; and inferential statistics of independent samples t-test. The results indicate that the sample scored lower in principled moral reasoning than undergraduate students in general. However, they scored predominantly at stage 4 in Kohlberg's moral judgment theory. Results also indicate that there are no significant differences in principled moral reasoning of the participants according to their gender.
\end{abstract}

Keywords: Principled moral reasoning, gender, undergraduate students, Defining Issues test, moral judgment, Kohlberg theory.

\section{Introduction and theoretical background}

Moral development has been an issue of major concern and an area of extensive research and study among philosophers and researchers in the social sciences throughout the ages. Earlier studies in moral development, however, were not psychological in nature and were, in effect, more of an examination of public moral knowledge, rather than personal moral beliefs of levels of moral thinking. Thus, despite the tremendous attention directed to the complexities of moral conduct throughout the ages, there has been little empirical investigation of the several theories on ethical behavior. The scientific research approach to moral development, in fact, began only during the last sixty years; and one of the earliest attempts to systematically contribute to moral development research in the area of moral development with a cognitive orientation was carried out by Piaget (1965).

\section{Piaget's Theory of Moral Development}

According to Piaget, the essence of morality is found in the individual's understanding of and respect for rules of the social order and his sense of justice in terms of concern for reciprocity and equality among individuals. Piaget evolved a system of two major stages of moral development which embodied the characteristic features of children's moral thinking suggested by the respect for rules and the sense of justice. The first major stage is referred to variously as moral realism, morality of constraint, or heteronomous morality. The second major advanced stage is called autonomous morality, morality of cooperation, or reciprocity.

\section{Heteronomous morality}

During this stage the child tends to obey adult commands and adhere to rules without questioning them. The child feels an obligation to comply to rules because they are sacrosanct and unchangeable. He judges the rightness or wrongness of an act because of the magnitude of its consequences. He believes in "immanent justice", that is, violations of social norms are followed by physical accidents or misfortunes emanating from some inmate force or object or from God. At this stage the child is a moral realist and considers rules and regulations as absolute in application. This attitude is believed to be supported by two major cognitive limitations in the young, s children thought. These are egocentricism and realism: egocentricism means that the child is really interested only in himself and his own concerns and is indifferent to the concerns of his peers. He does not take the others' point of view into consideration and does not understand reciprocal relationships. Realism means the child's inability to distinguish between subjective and objective aspects of his experience. This is mainly exemplified in his perception of dreams as external events rather than mental phenomena. As a result of these two cognitive limitations the child assumes there is only one view, which is shared by all, about whether an act is right or wrong, and he sees moral rules as fixed and unchangeable. 


\section{Autonomous morality}

In this stage the child does not view rules as sacred and unchangeable but as established and maintained through reciprocal social consent. The child gives his moral absolutism and recognizes a possible diversity in views of right and wrong. This stage is marked by stress on the importance of intent: the subject can consider the many mitigating circumstances that influence actions and intentions. Transition to this level is assumed to develop out of peer group interaction with the growing awareness of the need for mutual respect or reciprocity. And indeed as Lickona states: "All children make the transition from constraint to cooperation unless the development is retarded by deprivation of the opportunity for reciprocal interaction" (Lickona, 1976, p.221).

\section{Kohlberg and Moral Reasoning}

Based upon Piaget's (1965) conception of moral reasoning, Kohlberg conducted empirical and longitudinal studies which revealed six developmental stages allotted to three moral levels. Kohlberg demonstrated an evolution through the stages of moral reasoning development and delineated six stages within three different levels as follows:

\section{Pre-Conventional Level}

Stage 1: The Punishment and Obedience Orientation- Orientation to punishment, obedience, and physical and material power. Rules are obeyed to avoid the consequence of punishment. Avoidance of punishment and unquestioning deference to power are valued in their own right, not in terms of respect for an underlying moral order supported by punishment and authority.

Stage 2: The Instrumental Relativist Orientation- Naïve instrumental hedonistic orientation. The child conforms in order to obtain rewards. Right action consists of that which instrumentally satisfies one's own needs and occasionally the needs of others. Human relations are viewed in terms like those of the market place. Elements of fairness, reciprocity, and equal sharing are present, but they are always interpreted in a physical or pragmatic way. Reciprocity is a matter of "you scratch my back and I'll scratch yours", not of loyal, gratitude, or justice.

\section{Conventional Level}

Stage 3: The Interpersonal Concordance of "Good Boy-Nice Girl” Orientation- Good behavior is that which pleases or helps and is approved by others. There is much conformity to stereotypical images of what is majority or natural behavior. Behavior is frequently judged by intention. "He means well" becomes important for the first time, and a person earns approval by being nice.

Stage 4: The Law and Order Orientación- This is an orientation toward authority, fixed rules, and the maintenance of the social or religious order. Right behavior consists of doing one's duty, showing respect for authority, and maintaining the given social order for its own sake.

\section{Post-Conventional, or Principled Level}

Stage 5: The Social-Contract Legalistic Orientation- Generally characterized with utilitarian overtones. Right action tends to be defined in terms of general individual rights and in terms of standards that have been critically examined and agreed upon by the whole society. Emphasis is upon equality and mutual obligation within a democratic order. There is an awareness of relativism of personal values and the use of procedural rules in reaching consensus. Special significance given to the legal point of view, but with an awareness that law can be changed when considering societal utility.

Sage 6: The Universal Ethical Principle Orientation- Right is defined by the decision of conscience in accord with selfchosen ethical principles appealing to logical comprehensiveness, universality, and consistency. These principles are not concrete like the Ten Commandments but are more abstract like the Golden Rule. (Kohlberg, 1981, 1987; Gibbs, Basinger, \& Fuller,1992)

Rest's contribution to Moral Development theory: Although James Rest accepts many aspects of Kohlberg's conceptual theory and assumes that developmental stages of moral judgement invole distinctive ways of defining sociomoral dilemas and of evaluating the crucial issues in them, he can be considered the first major investigator to seriously question several facets of Kohlberg's wok. Rest (1986) believes that there are many complexities of development that the stage theory cannot explain. He points out that Kohlberg is continuing to make more changes in his scoring system of stages of moral development, and that final empirical verification of the exact nature of stage theory is not at all complete. In publishing the Defining Issues test (DIT), Rest constructed an alternative instrument for measuring moral judgement. (a full description of the Defining Issues Test (DIT) will be provided in the method and procedure section). Rest's $(1986,1990)$ significant contribution to the theory of moral development involves the construction of the (DIT). The present research employs the (DIT) to measure the moral reasoning of the participants in the study. 


\section{Review of Literature}

Since Kohlberg's inception of his theory, considerable amount of research was done utilizing his theory of cognitive moral development to describe the college student populations. Recent years, however, have witnessed a growing interest and concern among researchers in studying the moral reasoning of undergraduate and graduate students. These studies are especially important because the level of moral development is a critical component in determining what moral decisions people make and what actions they take.

Thus, a substantial amount of research on the moral reasoning of undergraduate and graduate students has been undertaken in a wide variety of cultural groups, predominantly, however, in the United States (e.g. Forte, (2013) ;Nettleton, ( 2018); McMahon, ( 1992); Wade, (2015); However, there is a dearth of empirical research regarding moral development of Muslim undergraduate and graduate students. To the best knowledge of the present authors, based on a comprehensive review of relevant literature, only few studies have been attempted on high schools and undergraduate students from Arab Muslim cultures (e.g. Bouhmama, 1984, 1988, 1989, 2007; Ismail, 1976; Maqsood, 1977, 1998;)

\section{Gender and Moral Reasoning}

An important variable studied by moral psychology researchers which have generated considerable interest over time is gender and its influence on moral reasoning. There are different findings about the nature of the impact of gender variable on moral reasoning. Some previous studies did not find any significant differences about students' moral reasoning in terms of gender, (Walker, de Vries, and Trevethan (1987), Walker (1989), and Stephens (2009). Other studies found significant differences favoring male students. (Haan, Langer, and Kohlberg (1976), Holstein (1976), and Weinreich-Haste (1977)

On the other hand, several researchers reported that female students have higher moral reasoning stages than male students (Bebeau, 2002; Cesur, 1997; Gibbs, Basinger, Grime, \&Snarey, 2007; Krebs \& Gillmore, 1982; Park \& Johnson, 1984; Tolunay, 2001). Gielen (1996), and Thoma (1986) conducted meta-analysis studies including the nature of the relationship between gender and moral development and reported that there is not any significant relationship between gender and moral development. They also stated that if there was a difference in terms of gender, this difference favored females:

Nettleton, (2018) conducted a study to explore the impact of gender on students' moral reasoning development while in college. The findings suggest both similarities and differences across gender, which may shed light on possible gender differences in moral reasoning outcomes in college. Better understanding of the role that gender plays in student choices could inform college administrators around issues that impact student participation and, therefore, meaningful development while in college. In a quantitative descriptive study Wade, (2015) examined the impact of gender on the moral reasoning development levels of undergraduate teacher education students. To measure their moral reasoning, he employed the DIT instrument of James Rest. Results revealed that moral reasoning development scores based on gender were not statistically significantly different.

In another study Kalsoom, et al (2012) conducted a piece of research to investigate the moral reasoning of adolescent boys and girls with reference to responsibility orientation versus justice orientation. The main conclusions of the study indicated that adolescent girls were found to be more care oriented than boys, however, they were found to be equal on justice oriented. It was also inferred that religion is the most important factor which influences the moral judgment and justice-oriented approach of boys and girls. It was also concluded that cultural norms do play an important role to make the boys more assertive to boys as compared to girls. It is expected from girls that they should be submissive, introvert and caring as compared to boys.

McMahon (1992) designed a study to investigate the relationship between moral development and gender. Moral development was measured by the Defining Issues Test (DIT). The sample consisted of 320 male and female students enrolled as full-time at The University of Iowa. The results showed significant gender $(\mathrm{p}<0.001)$ effects when analyzing the \%P score of moral development level. Women scored significantly higher than men.

Richard \& White (1999) examinad the effect of gender upon moral development of 299 male and female members of the U.S. Coast Guard. The study used Kohlberg's moral development framework to operationalize levels of moral judgment, and it employed Rest's Defining Issues Test (DIT) as a measurement instrument. The results revealed that females scored higher than males on the DIT. In a recent study, Walker, Thoma, Jones, \&Kristjánsson, (2017) assessed an important component of character-moral judgement - among 4053 pupils aged 14-15. Data were generated in 33 UK schools of varying types. Overall average results showed that females scored significantly higher than males. 


\section{The purpose of the study}

The purpose of the present research was to investigate the moral reasoning levels of a sample of undergtraduate students in the collge of Education Kuwait University.

Two reseach questions guided the authors in this investigation:

1. What is the principled moral reasoning level of undergtraduate students as measured by the Defining Issues test (DIT) ?

2. Are there differences in moral reasoning abilities of undergtraduate students based on their gender?

\section{Participants}

A convenience sample of 67 subjects, 27 males and 40 females varying in age from 19 to 25 (age $\mathrm{M}=18.64$ years, SD $=1.20$ years) participated in this study. They were all enrolled in education courses during the second semester of 2019, at the college of Education, Kuwait university. It might be useful to note here that though the sample may appear small, there have been a considerable amount of published studies relating to the DIT, among which a sample size of 50 to 100 is common (Coleman \& Wilkins, 2002)

\section{The Defining Issues Test measurement}

The Defining Issues Test (DIT) is a multiple-choice questionnaire derived from Kohlberg's theory of moral development (Rest, 1974). It was developed by Rest in a series of investigations at the University of Minnesota and has generated considerable research. The DIT consists of six moral dilemmas, three of which were taken from Kohlberg (1958), and three from Lockwood (1970). Extensive interviewing had provided norms for responses to these dilemmas. After reading each dilemma, the first task for the subject is to choose from one of three alternatives: a positive resolution; a negative resolution; or can't decide, after facing his or her own position in the dilemma, the second task is to rate a series of twelve statements about their importance in considering the moral issues involved. This task is done separately for each of the six dilemmas. The statements are rated on five-point Likert-type scales which range from 'great importance' to 'no importance'. The statements to be rated were to exemplify one of the following stages: (2): Morality of instrumentation and meeting one's needs and interests. (3): Morality of being good and living up to others' expectations. (4): 'Law and order' morality involving support of absolute authority. (A): Anti-established orientation of late adolescence involving rejection of conventional morality. (5A): Morality of upholding relative rules, democracy, and the social contract; (5B): Morality of intuitive humanism, in which obligation stems from 'certain ideals'.

(6): Morality of self-chosen universal principles of ideal social co-operation and justice.

In the third task the subject is asked to rank what he considers to be the four most important issue statements of the twelve given with the dilemma stories. This task is done separately for each of the six dilemmas. A variety of scores can be derived from these ratings and rankings. The DIT yields the following scores: (1) The P-score: is the combined weighed ranks of items keyed as stages 5 and 6 . It is obtained by summing the weights given to the principled stages 5A, 5B and 6. The P-score is interpreted by Rest (1986) as 'the relative importance a subject gives to principled moral considerations' (p. 110) and is considered to be the most useful and reliable index of moral development. The \% Pscore is a translation of the P-score into percentage. Such a percentage score will range from 0 to 90 (not 100), since on three stories, there is no fourth possible principled item to choose (Rest, 1974). (2) The D-score: is measure used by Davison (1977 and Davison, Robbins and Swanson (1978). It yields an overall composite index of the development based on weighted rating of Davison 's data. Unlike the P-score, the D-score is entirely based on ratings of moral issues rather than ranking of issues. The $\mathrm{D}$-score is based on information from items associated with every stage, whereas the P-score only reflects subjects' scores at stages 5A, 5B and 6. (3) The A-score: refers to items which represent an 'antiestablishment' orientation, a point of view which condemns traditions and the existing social order for its arbitrariness, corruption and exploitation of the poor. The DIT has been used extensively since the1970s and is still" the most widely used measure of moral judgment development with samples of undergraduate college students to investigate a broad range of moral issues" (Thoma, 2002, p. 225)

Currently, the number of studies using the DIT totals well over hundreds of thousands of respondents in more than 40 countries have taken the DIT. About 150 new studies involving the DIT are published each year (Rest, 1994)

\section{Procedure}

A short version of Rest's Defining Issues Test (DIT) was employed in the present study. It included the following three stories: "Heinz and the Drug", "The Doctor Dilemma", and "Escaped Prisoner". After the authors had prepared an initial translation of The English short version of the Defining Issues Test (DIT) into Arabic - the participants' mother language- it was then back-translated by two bilingual colleagues into English to check for accuracy of translation and idiomatic fluency. 
Minor changes had to be made in the content of the dilemma items in order to be consistent with the cultural environment of the participants (e.g. English names were changed to Arabic names). The translated Arabic of the short version of the DIT was administered to the participants in regular class session under the supervision of a research assistant. To assess the test reliability, 20 protocols were selected randomly and scored independently by a colleague conversant with the DIT. The interrater correlation was .98.

\section{Results}

In the present investigation, the authors sought to find answers to the two research questions listed below:

1.What is the principled moral reasoning level of undergtraduate students as measured by the Defining Issues test (DIT) ?

2.Are there differences in moral reasoning abilities of undergtraduate students based on their gender?

Research question 1: What is the principled moral reasoning level of undergtraduate students as measured by the Defining Issues test (DIT)?

Table 1 presents the distribution of moral stage scores for 67 undergraduate students in Education. These results answer the first question of the study related to the use of the sample of the Principled Moral reasoning level as measured by the P score of the Defining Issues Test (DIT).

Table 1: Distribution of DIT Moral stage scores.

$(\mathrm{N}=67)$

\begin{tabular}{|l|l|l|l|}
\hline & N & Mean & Std. Deviation \\
\hline Stage2 & 67 & 1.99 & 2.94 \\
\hline Stage3 & 67 & 10.52 & 7.30 \\
\hline Stage4 & $\mathbf{6 7}$ & $\mathbf{1 9 . 5 5}$ & $\mathbf{7 . 7 8}$ \\
\hline Stage5A & 67 & 7.31 & 5.42 \\
\hline Stage5B & 67 & 1.24 & 1.99 \\
\hline Stage6 & 67 & 2.98 & 3.18 \\
\hline Stage A & 67 & 1.81 & 2.79 \\
\hline Stage M & 67 & 3.68 & 4.169 \\
\hline Stage P & $\mathbf{6 7}$ & $\mathbf{1 0 . 2 7}$ & $\mathbf{6 . 1 2 4}$ \\
\hline Valid N (listwise) & 67 & & \\
\hline
\end{tabular}

The results for the undergtraduate students for this study indicate that the percentage of their principled Moral reasoning level is 10.27as expressed by the $\mathrm{P}$ score. The scores from the DIT yielded an interesting pattern for the present sample. The sample mean of the principled moral reasoning score expressed by Rest P-score was considerably below $(\mathrm{P} \%=10.27)$ the group means in the normative data provided by Rest, 1994; Rest \&Narváez, 1994 (p.4), who reported that Junior high school subjects generally average in the 20s, the senior high school subjects generally average in the 30s, the college students average in the 40s, the graduate students (who are not specializing in majors emphasizing moral thinking) average in the 50s, and those graduate students who do specialize in moral thinking average in the $60 \mathrm{~s}$, (as indicated in Table 2 below ). 
TABLE 2: Different Groups on the DIT P Score*

\begin{tabular}{lcc}
\hline Groups & P-scores \\
\hline Moral philosophy and political science graduate students & 65.2 & 59.8 \\
Liberal protestant seminarians & 52.2 \\
Law students & 50 \\
Medical students & 49.2 \\
Practicing physicians & 47.6 \\
Dental student & 46.3 \\
Staff nurses & $\mathbf{4 2 . 8}$ \\
Graduate students in business & 42.3 \\
College students in general & 41.6 \\
Navy enlisted men & 40.0 \\
Adults in general & 31.8 \\
Senior high school students & 23.5 \\
Prison inmates & 21.9 \\
Junior high school students & 18.9 \\
Institutionalized delinquents &
\end{tabular}

*Rest, J. R., \&Narváez, D., (1994). Moral development in the professions: Psychology and applied ethics. Hillsdale, NJ: Erlbaum. (p.14)

It is also evident from the above table 1 above that the participants have a profile of moral development with stage 4 of moral reasoning as predominant (19.55). As can be seen from table 1, the means of the scores for the undergraduate students in education were higher for the conventional moral reasoning (19.55), than for the postconventional moral reasoning (10.27). Findings of the present research corroborate the findings of some previous research studies of moral reasoning in education students, which indicate that these students demonstrate significantly lower principled moral reasoning than college students major in other disciplines (Forte, 2013; Cummings, Dyas, Maddux, and Kochman, 2001; McNeel, 1994; Yeazell\& Johnson, 1988;)

Research question 2: Are there differences in moral reasoning abilities of undergtraduate students based on their gender?

The second question addressed in this study sought to determine if there are differences in the participants' scores on principled moral reasoning (P-score) in terms of their gender. Table 3 displays the Means, Standards Deviations of the participants according to gender.

\begin{tabular}{|l|l|l|l|l|l|}
\hline \multicolumn{5}{|c|}{ Table (3) : Scores of Males and females on Stage 4 and P-score } \\
\hline & Gender & N & Mean & Std. Deviation & Std. Error Mean \\
\hline \multirow{2}{*}{ Stage4 } & Male & 27 & 20.80 & 9.10 & 1.75 \\
\cline { 2 - 6 } & Female & 40 & 18.70 & 6.74 & 1.06 \\
\hline \multirow{2}{*}{ Stage P } & Male & 27 & 7.90 & 4.81 & .92 \\
\cline { 2 - 6 } & Female & 40 & 11.87 & 6.44 & 1.018 \\
\hline
\end{tabular}

Results from Table 3 above revealed that males scored higher on the conventional level (stage $4=20.80$ ) than females (stage $4=18.70)$; whereas, females scored higher on the postconventional level $(\mathrm{P}$ - score $=11.87)$ than males $(\mathrm{p}$-score $=7.90$ )

To ascertain the differences between the participants according to their gender, a t- test was performed. Table (4) summarizes the results.

Table (4) summarizes the t-test results (gender differences)

\begin{tabular}{|l|l|l|l|l|}
\hline \multicolumn{1}{|c|}{ Stages } & $\mathrm{t}$ & $\mathrm{df}$ & Sig. (2-tailed) & Mean Difference \\
\hline \multirow{2}{*}{ Stage4 } & 1.08 & 65 & .284 & 2.09 \\
\cline { 2 - 5 } & 1.02 & 44.72 & .313 & 2.09 \\
\hline \multirow{2}{*}{ Stage P } & -2.72 & 65 & .008 & -3.97 \\
\cline { 2 - 5 } & -2.88 & 64.24 & .005 & -3.97 \\
\hline
\end{tabular}


Results of the t-test from Table 4 indicate that there are no significant differences between the participants in moral reasoning at stage 4 (their predominant moral reasoning stage) according to their gender. $\mathrm{t}(65)=1.08, \mathrm{p}=\geq 0.05$. However, there were significant differences between males and females with regard to P-score. $\mathrm{t}(65)=1.08, \mathrm{p}=\leq$ 0.05 in favor of females.

\section{Discussion}

Results of the present study indicate that Kuwait students employ principled moral reasoning less than expected based on their level of education. Although all the respondents are undergraduate students, the obtained mean of principled moral reasoning (post conventional thinking) of 10.27 was far more less than Senior high school students (31.80) and less than adults in general (40.0) as reported by Rest and Narváez (1994), and indicating that in terms of moral judgment, the subjects in this study scored much lower than other western graduate student groups. However, respondents used stage 4 moral reasoning ("law and order moral orientation" or " maintaining norms") more frequently than stages related to principled moral reasoning of moral reasoning. These findings support Stewart and Sprint hall's ( 1993) and Mwamwenda (1991)'s findings of decreased P scores and increased stage 4 scores.

The profile of the moral reasoning of the present sample shows the predominance of the conventional morality and a descent in advanced stages, as it appears in other studies using the same instrument the DIT test and with different students' samples (e.g. Bouhmama, 2007; Mwamwenda, 1991).

The main thrust of this study was to explore the principled moral reasoning of a sample of undergraduate students in education at the University of Kuwait. The findings suggest that the participants would show less preference to advanced levels of moral reasoning (post conventional reasoning) than their counterparts in other similar investigations reported in moral development literature. This finding seems rather distressing, given their level of education .The low principled moral reasoning level of the participants suggest that more attention needs to be paid to their moral judgment development .This may require ethics and values education to be integrated throughout the curriculum , as the existing programs do not seem to offer such needed specific ethics courses, in addition to the introduction of a teaching methodology based on critical reflection to promote their higher level of moral reasoning, as suggested by previous research literature in the domain of moral development (Rest, 1994; McNeel,1994; Kohlberg, 1981). In the current undergraduate programs, no interactive ethics course is provided, and the students are not exposed to think about ethical issues which promote growth of moral reasoning by stimulating cognitive dissonance and encouraging them to reason at a higher moral level than their current stage.

\section{References}

Baumrind, D. (1986). Sex differences in moral reasoning: Response to Walker's (1984) conclusión that there are none. Child Development, 57, 511-52

Bebeau, M. J. (2002). The defining issues test and the four component model: Contributions to profesional education. Journal of Moral Education, 31(3), 271-295.

Bouhmama, D. (2007) Patterns of moral reasoning and their relationship with sex and educational level of a sample of Kuwait University students. The Educational Journal, 21(84), pp. 13-51. (in Arabic)

Bouhmama, D. (1984). Assessment of Kohlberg's stages of moral development in two cultureses. Journal of Moral Edu cation, 13 (2), 124-132

Bouhmama, D. (1988). Relation of formal education to moral judgment development Journal of Psychology, 122 (2), $155-158$

Bouhmama, D. (1989). The moral judgment of Algerian University students. The Educational Journal, 6 (21), 107-134.

Bussey, K., \& Maugham, B. Gender differences in moral reasoning. Journal of Personality and Social Psychology, 1982,42,701-706.

Cesur, S. (1997). The relationship between cognitive and moral development. , Yayınlanmamış yüksek lisans tezi, Boğaziçi Üniversitesi, İstanbul.

Cesur, S \&Topcu, M.S (2010) A Reliability and Validity Study of the Defining Issues Test: The Relationship of Age, Education, Gender and Parental Education with Moral Development, Educational Sciences: Theory \& Practice 10 (3), 1681-1696)

Coleman, R., \& Wilkins, L. (2002). Searching for the Ethical Journalist: An Exploratory Study of the Moral Development of News Workers. Journal of Mass Media Ethics, 17(3), 209-225.

Cummings, R., Dyas, L., Maddux, C. D., \&Kochman, A. (2001). Principled moral reasoning and behavior of preservice teacher education students, American Education Research Journal, 38(1), pp. 143-158.

Davison, M.L, (1977). On a dimensional metric unfolding model for attitudinal data. Psychometrika, 42, 523- 548 
Davison, M.L, Robbins, S\& Swanson, D (1978). Stage structures in objective moral judgment. Developmental Psychology, 14 (2), 137-146

Dennis L. Krebs, Sandra C. Vermeulen, Kathy L. Denton \& Jeremy I. (1994) Gender and Perspective Differences in Moral Judgement and Moral Orientation, Journal of Moral Education, 23:1, 17-26.

Ford, R. M., \& Lowery, R. C. Gender differences in moral reasoning: A comparison of the use of justice and care orientations. Journal of Personality and Social Psychology, 1986, 50, 777-785

Forte, A. (2013). The Moral Reasoning of Sports Management Students in The United States and Italy. Journal of International Education Research (JIER), 9(2), 177-198.

Geri R. Donenberg and Lois W. Hoffman (1988) Gender Differences in Moral Development Sex Roles, Vol. 18, Nos.11/12.

Gibbs, J.C., Basinger, K.S\&Fuller, D. (1992) Moral Maturity: Measuring the Development of Sociomoral Reflection. Hillsdale, NJ: Lawrence ErlbaumAssociates

Gibbs, J. C., Basinger, K. S., Grime, R. L., \&Snarey, J. R. (2007). Moral judgment development across cultures: Revisiting Kohlberg's universality claims. Developmental Review, 27, 443-500.

Gielen, U. P. (1996). Moral reasoning in cross-cultural perspective: a review of Kohlbergian research. World Psychology, 2(3-4), 313-333.

Glover, R. J. (1997). Relationships in moral reasoning and religion among members of conservative, moderate, and liberal religious groups. The Journal of Social Psychology, 137(2), 247-255.

Haan, N., Langer, J., \& Kohlberg, L. (1976). Family patterns of moral reasoning. Child Development, 47, 1204-1206

Holstein, C. B. (1976). Irreversible, stepwise sequence in the development of moral judgment: a longitudinal study of males and females. Child Development, 47, 51-61.

Ismail, M.A. (1976) A cross-cultural study of moral judgment: the relationships between American and Saudi Arabian University students on the defining issues test. Unpublished doctoral dissertation, Oklahoma State University

Kalsoom, F, Behol. M.G, Kayani, M.M. \&Kaini, A (2012). The Moral Reasoning of Adolescent Boys and Girls in the Light of Gilligan's Theory, International Education Studies Vol. 5, No. 3.

Kohlberg, L. (1958). The development of modes of mortal thinking and choice in the years ten to sixteen. Unpublished doctoral dissertation, University of Chicago

Kohlberg, L. (1984). The psychology of moral development: The nature and validity of moral stages. New York: Harper and Row

Kohlberg, L. (1981). The philosophy of moral development: Moral stages and the idea of justice. San Francisco: Harper \&Row.

Kohlberg, L. (1987). Child psychology and childhoodeducation: A cognitive-developmentalview. New York: Longman

Krebs, D., \&Gillmore, J. (1982). The relationship among the first stages of cognitive development, role-taking abilities, and moral development. Child Development, 53, 877-886

Lickona, T (1976) Moral development and behavior : theory, research, and social issues New York : Holt, Rinehart and Winston

Lockwood, A (1970). Relations of political and mora; thought. Unpublished doctoral dissertation, Harvard University

McMahon. T.R, (1992). The Relationship Between Moral Development and Personality Type of University Undergraduates. Unpublished Ph.D. dissertation

McNeel, S. (1994) College teaching and student moral development. In J. Rest, \& D. Narvaez (Eds.), Moral development in the professions: Psychology and applied ethics (pp. 27-49). Hillsdale, NJ: Erlbaum.

Maqsud, M. (1977). Moral reasoning of Nigerian and Pakistani Muslim adolescents. Journal of Moral Education, 7 (1), 40-49

Maqsud, M. (1998). Moral orientations of Batswana high school pupils in South Africa.

Journal of Social Psychology, 130, 255-257.

Mwamwenda, T. (1991) Graduate students moral reasoning, Psychological Reports, 68(3) pt2, pp 1368-1370.

Nettleton, J. A (2018) Moral Reasoning, Gender and Student Participation While in College. ProQuest LLC, Ed.D. Dissertation, University of Pennsylvania

Park, J. Y., \& Johnson, R. C. (1984). Moral development in rural and urban Korea. Journal of Cross-cultural Psychology, 15(1), 35-46

Piaget, J (1965) The mortal judgment of the child. New York: Free Press, 1965.

Rest, J. (1990) DIT manual (Minneapolis, Minnesota, USA: University of Minneapolis Press).

Rest, J. R. (1986). Moral Development: Advances in Research and Theory. Minneapolis, MN: University of Minnesota Press 
Rest, J. R. (1974). Manual for the Defining Issues Test: An objective test of moral judgment development. University of Minnesota.

Rest, J. (1979). Development in judging moral issues. Minneapolis: University of Minnesota Press.

Rest, J. R. (1994). Background: Theory and research. In J. R. Rest \& D. Narvaez (Eds.), Moral development in the professions: Psychology and applied ethics (pp. 1-26). Hillsdale, NJ: Erlbaum

Rest, J. R., \& Narvaez, D. (Eds.). (1994). Moral development in the professions: Psychology and applied ethics. Hillsdale, NJ: Erlbaum

Rest, J.R. (1979). Development in Judging Moral Issues. University of Minnesota Press.

Rest, J. R. (1994). Background: Theory and research. In J. R. Rest \& D. Narvaez (Eds.), Moral development in the professions: Psychology and applied ethics (pp. 1-26). Hillsdale, NJ: Erlbaum

Rest, J. R. (1986). Moral Development: Advances in Research and Theory. Minneapolis, MN: University of Minnesota Press

Rest, J. R., \& Narvaez, D. (Eds.). (1994). Moral development in the professions: Psychology and applied ethics. Hillsdale, NJ: Erlbaum

Rest, J., \& Narvaez, D. (1998). Guide for DIT-2. Minneapolis: University of Minnesota

Rest, J., Narvaez, D., Bebeau, M. J., \&Thoma, S. J. (1999a). A neo-Kohlbergian approach: The DIT and schema theory. Educational Psychology Review, 11, 291-324.

Rest, J., Narvaez, D., Bebeau, M. J., \&Thoma, S. J. (1999b). Postconventional moral thinking: a Neo-Kohlbergian approach. Mahwah, NJ: Erlbaum.

Rest, J., Thoma, S., \& Edwards, L. (1997). Designing and validating a measure of moral judgment: Stage preference and stage consistency approaches. Journal of Educational Psychology, 89, 5-28.

Rest, J., \& Narvaez, D. (1998). Guide for DIT-2. Minneapolis: University of Minnesota.

Richard D. White, Jr. (1999). Are Women More Ethical? Recent Findings on the Effects of Gender upon Moral Development. Journal of Public Administration Research and Theory: J-PART, Vol. 9, No. 3 pp. 459-471 Stephens, D.G. (2009). A correlation study on parental attachment and moral judgment competence of millennial generation college students, Unpublished doctoral dissertation, The Graduate College at the University of Nebraska, Lincoln, Nebraska.

Stewart, Debra W., and Sprinthall, Norman A. (1993) The Impact of Demographic, Professional and Organizational Variables and Domain on the Moral Reasoning of Public Administrators. In H.G. Frederickson, (Ed.). Ethics and Public Administration, Armonk, N.Y.: Sharpe.

Thoma, S. J. (2002). An overview of the Minnesota approach to research in moral development. Journal of Moral Development, 31(3), 225-245.

Thoma, S.J (1986) Estimating Gender Differences in the Comprehension and Preference of Moral Issues. Developmental Review 6, 165- 180 (1986)

Tolunay, A. (2001). The relationship between religiosity, dogmatism and moral reasoning, Yayınlanmamıs yüksek lisans tezi, Boğaziçi Üniversitesi, İstanbul.

Wade, M (2015) A study of moral reasoning development of teacher education students in Northern Louisiana, , Unpublished doctoral dissertation, University of phoenix

Walker, D. I., Thoma, S. J., Jones, C., \&Kristjánsson, K. (2017). Adolescent moral judgement: A study of UK secondary school pupils. British Educational Research Journal, 43(3), 588-607. doi:10.1002/berj.3274

Walker, L. J. (1989). A longitudinal study of moral reasoning. Child Development, 60, 157-166.

Walker, L. J., de Vries, B., \&Trevethan, S. D. (1987). Moral stages and moral orientations in real-life and hypothetical dilemmas. Child Development, 58, 842-858.

Weinreich-Haste, H. (1977). Some consequences of replicating Kohlberg's original moral development study on a British sample. Journal of Moral Education, 7, 32-39

Yeazell, M.I., \& Johnson, S.F. (1988) Levels of moral judgment of faculty and students $\mathrm{n}$ a teacher education program: A micro study of an institution, Teacher Education Quarterly, 15(1), pp.61-70. 